\title{
BEVEZETÉS A PANNON EGYETEM GAZDASÁGTUDOMÁNYI KARÁN FOLYÓ TUDOMÁNYOS KUTATÁSOK EREDMÉNYEIT BEMUTATÓ TANULMÁNYOKHOZ
}

M int az az olvasók számára köztudott, a Vezetéstudomány folyóirat vezető szerepet tölt be a hazai menedzsmenttudományok szakterületén. Számos elméleti és gyakorlati tanulmány publikálását teszi lehetővé évente, melyek a vállalati gyakorlat szakemberei számára ugyanúgy, mint a felsőoktatási intézmények oktatói és hallgatói számára aktuális és naprakész információkat nyújtanak. Hálásak vagyunk - a Pannon Egyetem Gazdaságtudományi Karának munkatársai - azért, hogy lehetőséget kaptunk arra, hogy a széles körü, érdeklődő szakmai közösség számára bemutathatjuk aktuális kutatásaink néhány kis szeletét. A tanulmányok két nagy szakterület köré csoportosíthatók. Négy tanulmány foglalkozik a szükebb-tágabb környezetünk (Veszprém-Balaton régió) aktuális problémáit, kihívásait érintő kérdésekkel, míg három további tanulmány egy - az egyetemen és a karon is - kiemelt jelentőséggel kezelt kutatási projekt eddigi eredményeibe ad betekintést. A nyolcadik tanulmány a folyóirat eredeti küldetéséhez hűen a vezetéstudomány örök kérdését boncolgatja, mely napjainkban is az egyik leginkább aktuális kérdés. Nevezetesen az autentikus vezetés jellemzőit, hazai gyakorlatban történő alkalmazásának mintáit mutatja be a szerzői közösség.

Ezen utolsóként említett tanulmány tizenöt hazai vezető életútjának kvalitatív elemzésével segít megérteni a hazai gyakorlatban még ritkán vizsgált vezetési stílusnak az elvárásait, szükséges paramétereit, melyek lehetőséget kínálnak az érdeklődők számára követni, tanulni történeteikböl. A kutatásban készített interjúk elemzése négy fő területre fókuszált: gyermekkori traumák és nehézségek, fordulópontot jelentő élettörténeti események, a vezetővé válás és vezetői szemlélet, valamint a vezetö által vallott értékek. Legfontosabb következtetéseik, hogy az autentikus vezető hitelessége abból fakad, hogy interpretálja és integrálja meghatározó életeseményeit önmaga megismerése és fejlesztése céljából. Az autentikus vezető vezetővé válásának alapvető motivációja saját belső indíttatásából fakad, a vezetői tevékenység az önkifejezés eszköze. A vezetők tetteiben eröteljesen megjelennek az erkölcsi, morális értékek, ezeken kívül értékként jelenik meg a tisztesség, az emberségesség, a bizalom és a felelősség. A kutatás alátámasztotta, hogy a vizsgálatban részt vett magyar felső vezetők rendelkeznek az autentikus vezetőre jellemző tulajdonságokkal és vezetői munkájuk- kal összefüggő személyiségjegyeik mélyebb elemzése, a téma kutatása további lehetőségeket rejt az érdeklődők számára.

A Veszprém-Balaton régió területén végzett kutatások kvalitatív és kvantitatív formában igyekeztek megvilágítani olyan összefüggéseket, jellemzőket, problémákat és lehetőségeket, melyek a vizsgált területen kívül bárhol másutt is hasznosítható eredményeket jelentenek. Több tanulmány a szolgáltatási szférát célozza, (nem véletlenül), hiszen ebben a régióban a turizmus és az ahhoz kapcsolódó szolgáltatások kiemelt figyelemmel kezelendők.

„A kölcsönös értékteremtéssel kapcsolatos elvárások modellezése a szolgáltatásokban" címü kutatás a szolgáltatáspiacon megvalósuló fogyasztói döntéshozatal vizsgálatára fókuszál, megvilágítva az igénybe vevői preferenciákban megjelenö kölcsönösen elvárt tartalmat. A tanulmány célja, hogy hozzájáruljon a turisztikai igénybevevők és szolgáltatók közötti közös értékteremtés megismeréséhez. A fogyasztók szolgáltatásválasztása során lezajló döntéshozatali folyamatokat fókuszcsoportos interjúkon alapuló kvalitatív elemzéssel tárja fel, figyelmet fordítva az értékteremtés szempontjaira a fogyasztói preferenciákban. A tanulmány egy modellt javasol, egy lehetséges keretrendszert, mely tartalmazza a kölcsönös értékteremtés elemeit arra vonatkozóan, hogy milyen dimenziók és paraméterek mentén lehet azonosítani a kölcsönös elvárásokhoz való igénybe vevői viszonyt. A modell jó közelítéssel általánosítható az összes szolgáltatásra, de szolgáltatástípusonként a hangsúlyok máshova kerülhetnek, az egyes dimenziók szerepe és súlya függhet a szolgáltatások típusától. A modell kvalitatív kutatáson alapuló hipotetikus struktúra, amelyet kvantitatív kutatással a továbbiakban validálni szükséges.

A „Települési tényezők fontosság-elégedettség elemzése a Balaton térségben" címü tanulmány célja megtalálni, hogy milyen települési fejlesztésekre vágynak leginkább a Balaton környékén élő emberek. Ennek érdekében a Balaton kiemelt turisztikai fejlesztési térség településeihez kötődő lakosság véleményét vizsgálták a szerzők, az egyes települési tényezők fontosságát és az ezekkel való elégedettséget. A tanulmányban használt módszertan mind a gyakorlati, mind a tudományos szakemberek számára használható keretrendszert alkalmaz. A kutatás során feltételezték, hogy a különbö- 
ző generációk véleménye eltér, ezért az eredményeket e két korcsoportra bontva mutatják be. Ez alapján finomíthatók a döntéshozóknak nyújtott fejlesztési ajánlások, attól függően, hogy az önkormányzat a fiatalabb vagy az idősebb lakosság preferenciáit helyezi előtérbe. A korábbiakban még nem készült ilyen felmérés és ajánlás a Balaton térségére vonatkozóan.

$\mathrm{Az}$ ebben a témakörben készült harmadik tanulmány - „A dolgozói elégedettség vizsgálata a belső CSR-tevékenységek tükrében" címmel - szintén az elégedettséget vette górcső alá, és azzal összefüggésben a szervezetek belső CSR-tevékenységét. A kutatás elméleti háttere arra épít, hogy a társadalmi felelősségvállalás alapvetően két dimenzióban nyilvánulhat meg: a külső és a belső CSR formájában. E kettő közül a vállalatok főként a külső CSR-ra összpontosítanak. A kutatók kíváncsiak voltak arra, hogy a belső CSR, amely közvetlenül a munkavállalók fizikai és pszichológiai környezetéhez kapcsolódik, milyen összefüggést mutat a munkatársi elégedettséggel és mekkora figyelmet kap ez a kapcsolat a szervezetek vezetőitől. Az elégedettség kialakulásában fontos szerepe van annak, hogy az elvégzett munkát és az érte kapott javadalmazást mennyire tekinti méltányosnak a munkavállaló, menynyire támogatók a munkafeltételek, a munkahelyi légkör, a vezető és a munkatársak. Ezeket a tényezőket, az azokkal kapcsolatos értékítéletet jelentős mértékben befolyásolják a belső CSR elmei, tehát összefüggésük vizsgálata megalapozott. A kutatás a Balaton régió négy- és ötcsillagos szállodáinak munkavállalóit célozta egy saját kutatási modell alapján, kérdőíves felmérés adatainak felhasználásával. Az eredmények igazolták, hogy a belső CSR alkalmazása alkalmas a dolgozói elégedettség növelésére, és a vizsgált szállodák mérete és tulajdonviszonyai nem befolyásolják létjogosultságát. Ezek alapján a kutatók fontosnak tartják a belső CSR vállalati stratégiába történő beillesztését.

A témakör negyedik tanulmánya „A Pannon Egyetem közösségének kultúrafogyasztása, az érzelmi és kulturális intelligencia összefüggése - Veszprém 2023 Európa Kulturális Fővárosa" címmel az egyik legfontosabb és leginkább aktuális kihívás néhány kérdését járja körbe. Mivel 2023-ban Veszprém lesz Európa Kulturális Fővárosa, ez olyan elvárásokat és felkészülést jelent a szükebb-tágabb környezet számára, melyhez kapcsolódó néhány alapvető kérdés vizsgálatát feltétlenül szükségszerünek ítélték a szerzők. Az EKF (Európa Kulturális Fővárosa) kutatócsoport a Pannon Egyetem közösségének „kultúrafogyasztását”, helyi identitását, életminőségét, érzelmi és kulturális intelligenciája közötti összefüggéseket boncolgatja egy longitudinális felmérés keretében. Mivel a 2023-as év Európa Kulturális Fővárosa számára komoly lehetőségeket jelentenek a cím elnyerésével járó további kulturális és egyéb szabadidős fejlesztések, (melyek növelik a város kulturális vonzerejét és munkahelyteremtő képességét is), a kutatás, a címben jelzett összefüggések vizsgálata segítségével igyekezett feltárni azokat a kulturális elemeket, melyekre a fejlesztő beruházások és programok szer- vezése kapcsán érdemes figyelmet szánni. A kutatás elméleti hátterének kiinduló pontja az a gondolat, hogy a kulturális örökség a jövő generációk erőforrása. Ezért elengedhetetlen, hogy a jelen generációk tisztában legyenek saját örökségükkel, azok értékeivel, tiszteljék és felelősséget vállaljanak azokért. Kérdés, hogy a helyi lakosság, a turisták mint fogyasztók a kulturális tartalmú szabadidős tevékenységet milyen formában veszik igénybe? Milyen összefüggés mutatható ki az egyetemi közösség tagjainak kultúrafogyasztás-tényezői és érzelmi intelligenciájuk (EQ) szintje között? Milyen kapcsolat van az egyetemi közösség tagjainak kultúrafogyasztás-tényezői és kulturális intelligencia (CQ) szintje között? A kérdés megválaszolásához kérdőíves felmérésen alapuló kvantitatív felmérést végeztek a kutatók. Az eredmények nem meglepő módon szignifikáns kapcsolatot mutattak a vizsgált tényezőkben, valamint az életkorral való összefüggés kimutatható a különböző kulturális programok preferenciájában.

A tanulmányok másik nagy csoportja, átfogó címen „Ipar 4.0 és digitalizáció” koncepcióhoz kapcsolódó, az ország több egyetemén - így Veszprémben - is folytatott kutatások különböző szempontú vizsgálati eredményeiről ad számot. A témakört leginkább megalapozó kutatás az elméleti hátteret igyekezett feltárni és összefoglalóan bemutatni „Az Ipar 4.0 a gazdaságtudományokban - A nemzetközi és hazai szakirodalom bibliometriai elemzése" című tanulmányban. Kiváló összegzése a témának, mely minden olyan szakember számára kiinduló olvasmányt jelenthet, aki mélyebben szeretné megismerni és további szempontok alapján kutatni a témát. Bár a témakör elsősorban a müszaki fejlődés eredményeként számon tartott, de számos egyéb kapcsolódása is feltárható a szakirodalomban. Az irodalomfeldolgozás az elmúlt évtizedre fókuszál, a gazdaságtudomány területéhez kapcsolódó témákat érintően. A szerzők a Clarivate Web of Science adatbázis alapján összeállított publikációs lista föbb bibliometriai jellemzői alapján gyakorisági és hálózati elemzési módszerek segítségével vizsgálták a publikációk kulcsszavait, absztraktjait, illetve címét. Széles körü összefonódást találtak az Ipar 4.0 és a gazdaságtudományi területek különböző témáival, és a fokozódó kutatói érdeklődés miatt egyre növekvő számosságban jelennek meg tanulmányok pl. a fenntarthatósággal, a lean koncepcióval, a motivációval és egyéb, az emberi erőforrás kezelésével összefüggő kérdések kutatása területén.

Ahogyan az irodalmi áttekintés is jelzi, az érdeklődés növekedése miatt az Ipar 4.0 és az emberi erőforrás - különösen a vezetői felkészültség, gondolkodás tekintetében - egyre gyakrabban tárgya a kutatásoknak. „A humánerőforrás-fejlesztés kihívásai a digitális átállás fényében - kihívások, reakciók, törekvések és várakozások" címü kvalitatív elemzés a vállalkozások digitális átállásával összefüggő humán erőforrás kihívásaira kereste a választ vezetői interjúk alapján. A kutatás eredményei azt mutatják, hogy bár a vezetők egyetértenek a digitális alapismeretek és az alapvető informatikai tudás szükségességében, az interjúkban 
mégsem ezen kompetenciákat emelték ki elsősorban, mint elvárt képességek. A megkérdezett vezetők kiemelték az oktatási intézmények megnövekedett szerepét nemcsak a digitális képességek elsajátíttatásában, de a „soft" skillek, a személyiség alakításában is.

A humán erőforrás felkészültségének vezetői oldalát kutatta a témakör harmadik tanulmánya, „Vezetői felkészültség felmérése a digitális kor kihívásaira - nemzetközi összehasonlítás" címmel, mely szintén kvalitatív módszertanra építve elemezte három nemzet iparvállalati felső vezetőinek véleményét arról, hogy milyen mértékben készültek fel szervezeteik a digitális jövőre, mi jelenti a legnagyobb kihívást számukra, és milyen vízióval rendelkeznek, mi a legfontosabb érték számukra a digitális jövőben. Az eredmények szerint a vezetők megtapasztalják a kihívásokat az online eszközök használata és a kommunikáció követelményein keresztül, látják és érzik a változásra történő felkészülés igényét, de a digitális stratégia alkotása, az innováció és a mesterséges intelligencia összekapcsolása, a vezetői stílusváltás még várat magára.

Reméljük, hogy a Pannon Egyetem Gazdaságtudományi Karának kutatásai érdekes és értékes ismereteket, információkat biztosítanak az olvasóknak, melyeket mind elméletben, mind gyakorlatban hasznosítani tudnak majd. 